\title{
Organizational Culture in the Formation of Character of Students Taking Care of Student Institutions Faculty of Social Science Makassar State University
}

\author{
Herman* \\ Departemen of History Education \\ Faculty of Social Science \\ State University of Makassar \\ Makassar, Indonesia \\ herman7505@unm.ac.id
}

\author{
Darman Manda \\ Departemen of History Education \\ Faculty of Social Science \\ Universitas Negeri Makassar \\ Makassar, Indonesia \\ darmanmandappspascasarjaunm@y \\ ahoo.com
}

\begin{abstract}
This study aims to determine the effect of the culture of student organizations on the character of students of the Faculty of Social Science, Makassar State University Student Organizations. This study uses a quantitative descriptive study with the student population of Faculty of Social Science, Makassar State University Student Institutional Management because the population is relatively small so there is no need to determine the sample. Data collection is done by using observations, questionnaires, and documentation. Data analysis techniques used are descriptive statistical analysis and inferential statistical analysis. The results of this study are: 1) The organizational culture picture of Faculty Of Social Science, Makassar State University students are in quite a good category, with benchmarks namely individual initiative, direction, integration, support from management, communication patterns, tolerance, control, reward systems, and identity. 2) The description of student character is in quite a good category, this is seen from the acquisition with the benchmark is the indicators of Trustworthiness, Fairness, Caring, Respect, Citizenship, Responsibility. 3) Based on the result of a product-moment calculation, the correlation between organizational culture and Faculty of Social Science, Makassar State University Student Character is obtained with the medium category. This means that the relationship between the culture of the Faculty of Social Science, Makassar State University organization and the Faculty of Social Science, Makassar State University Student Character
\end{abstract}

\section{Keywords: Intellectual, Entrepreneurial, Capital}

\section{INTRODUCTION}

Education is now believed to be a sector capable of realizing both intelligence and human personality to become better. The government-issued budget for the education sector reaches $20 \%$ of the education budget of $20 \%$ of total spending, this is in history and enforcing the compulsory study of 12 years, it proves that education is a priority to realize easy generation that can be useful for nations and countries [1].

Education is a conscious and planned effort to create a learning atmosphere and learning process so that students actively develop their potential to possess the spiritual power of religion, self-control, personality, intelligence, noble character and skills necessary to himself, society, nation, and state. Education not only forms intelligent human beings but has character personality. Thus, growing

generations develop with characters that have sublime values of the nation and religion [2].

After going through a compulsory education 12 years, a student will continue to a college-level known as students, at this level students are required to play a role in bringing the nation's change towards a better and required to be ready to contribute to society. According to what is listed in student roles and functions. Students are in full need of strong intentions and a deep understanding of the student's role as Agent of Change, iron stock, guardian of value, moral force, and social control. This role demands students to find out who they are, to the college level students are exempt to explore and be hosted by various organizations inside the campus[3].

Culture is a mind, intellect, customs, something that has developed a culture that has evolved, something that has become a habit that has been difficult to change. While the organization of a unity consisting of parts (people and so on) in the Assembly and so on for a particular purpose [4].

The implementation of such a culture in the organization became the organizational culture. Experts give an understanding of organizational culture in a very diverse way. Culture is a pattern of basic assumptions found and developed by a particular group because of studying and mastering the problems of external adaptations and internal integration, which has worked well enough to be considered worthily that the arena was taught to new members as a perceived way, thinking and perceived correctly about the problem[5].

Each organization has a culture of an organization that affects all aspects of the Organization and the behavior of its members individually and in groups. Culture is a system of value held and done by members of the organization, culture can distinguish the organization of one another [6].

Organizational culture is a way of doing things in the organization. Culture represents one of the sub-systems organizations that are analogous to the digestive system in the human body. Organizational culture is a fundamental 
artifact, rule, values, principles, and assumptions that can direct organizational behavior. Organizational culture can be interpreted as a pattern of basic assumptions found, researched, or developed by various groups in the organization [7].

Culture can be analyzed as a phenomenon that surrounds human life at all times because it is constantly portrayed and created by humans through interactions made with others. Four basic views on organizational culture that can be translated into four different hypotheses:

1) Hypothesis consistency. The notion that common perspectives, beliefs, and communal values among participants in the Organization broaden internal coordination and enhance the understanding of group members ' self-identification as part of his group.

2) the mission hypothesis. The idea that a sense of purpose, direction, and strategy can coordinate and galvanize members of the organization toward a common goal.

3) the involvement hypothesis. The idea that engagement and participation will contribute to a sense of responsibility and ownership, as well as to organizational commitment and loyalty.

4) hypothesized adaptation capabilities. Ideas of norms and beliefs that accelerate organizational ability to receive, interpret, and translate messages from the environment into the organization, and behavioral changes that support the presence, growth, and development of the Organization [8].

The hypothesis above in addition to focusing on different cultural aspects, also more important is that the hypothesis emphasizes the different cultural functions. The first two hypotheses tend to support stability, while the other two hypotheses tend to provide an opportunity for change and adaptation power. One and three hypotheses see a culture that focuses on the organization's internal dynamics, while the second and fourth hypothesis sees a culture that emphasizes organizational relationships with its external environment. The organizational culture hypothesis is related to the categorization of organizational effectiveness perspectives [8].

Emphasize the importance of three components of good character (components of good character), namely moral knowing or knowledge of moral, moral feeling or feelings about moral, and moral action or moral deeds. It is necessary so that the child can understand and work together with the values of virtue [9].

1) Moral knowing is the ability to know, understand, reinforce, distinguish and interpret the types of moral that must be done and that must be left out.

2) The moral feeling is the ability to feel guilty and feel the need for moral action. If you feel guilty about doing evil deeds, or feel the need/obligation to help someone else who has made our help, we have moral feelings.

3) Moral action is the result or outcome of two previous parts of the character, to move someone in a moral act or to prevent someone from not doing so.

His research said that the character formed after following the process as follows [10]:

1) The presence of values absorbed by a person from a variety of sources may be religion, ideology, education, findings themselves, or others.
2) The value of forming a mindset thinks of someone who overall comes out in the form of his vision.

3) The vision of descending into the realm of the heart forms an atmosphere of the whole soul forming mentality.

4) The flowing mentality enters the physical territory and spawned an action that is collectively called attitude.

5) The dominant attitude in a person who in the whole selfproclaimed himself is what is referred to as personality or character.

From an educational perspective, the intellectual and moral aspects cannot be separated from the formation of individual characters. Intellectual goodness prepares mental conditions where individuals can properly understand and choose the orientation. Similarly, moral goodness will be able to ensure good actions so that it characterizes the personality

Student characters can generally be defined through the following:

1) Academic character; Academic characters can be measured from aspects of academic achievement, academic honesty, and scientific attitudes of students. Student motivation is a supporting character of student achievement.

2) Non-academic characters; Non-academic characters are moral aspects or student attitudes. Non-academic characters can be observed from many aspects, such as noble values and national characters in students, paradigm thinking students, and understanding the national history of Indonesia and the student's national insight [11].

Six pillars that can be a reference, six Pillars of the character as follows [12]:

1) trustworthiness, a character form that makes one integrated, honest, and loyal.

2) Fairness, a character form that makes a person have an open mind and does not like to utilize others.

3) Caring, the shape of the character that makes a person has care and attention to the other person or social condition surrounding environment.

4) Respect, the form of character that makes a person always appreciates and respects others.

5) Citizenship, a form of character that makes people aware of laws and regulations and cares for the natural environment.

6) Responsibility, the form of character that makes a person responsible, disciplined, and always do something with the best possible.

\section{METHOD}

This type of research is quantitative research descriptive. This research is a study that examines the influence of organizational culture towards character building The variables of this research are the organizational culture (X) as an independent variable and the establishment of student character of the Institute of Social Sciences Faculty of Makassar State University (Y) as dependent variables.

The population is the entire data of concern, in a given scope and time. " So the population is the overall subject of research. The population of all management of the Faculty 
of Social Sciences of Makassar State University and which is the sample of the management research is said 2015, 2016, and 2017. In this research, there are several ways that authors will do in data collection, as follows: Observation, poll, documentation.

The data analysis techniques used by the authors in this study are by conducting descriptive statistical analyses and inferential statistical analyses. A descriptive statistical analysis technique is a data technique aimed at describing both variables using percentages and average analyses (mean).

\section{RESULT AND DISCUSSION}

\section{A. Organizational Culture Overview}

Each organization has a culture of the organization that affects all aspects of the Organization and the behaviour of its members individually and in groups. Organizational culture is a way of doing things in the organization. Culture represents one of the sub-systems organizations that are analogous to the digestive system in the human body. To find out the organizational culture at the Faculty of Social Sciences of Makassar State University. students can see the following chart:

Chart 1. Student organization Culture Faculty of Social Sciences Makassar State University.

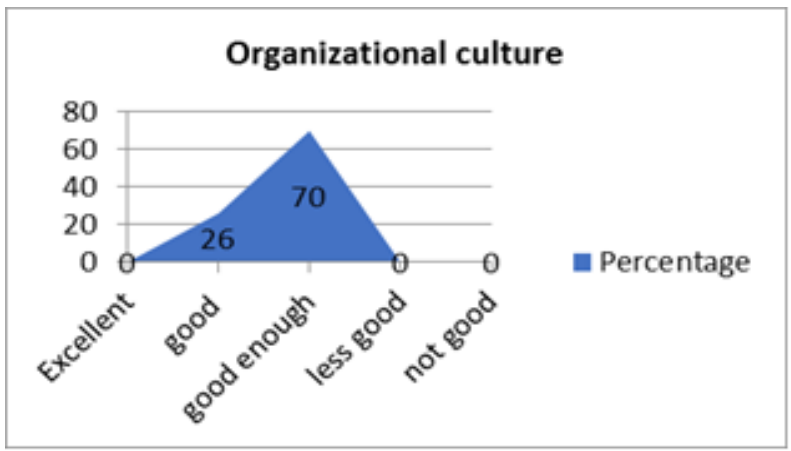

Based on the table above, it can be concluded that the organizational culture is still a good category, and the rest is less good, in this case, the organizational culture that occurs in the Faculty of Social Sciences is likely to be done only formality, and tend not to develop. Activities performed are only activities conducted as the year before. The attention of leadership is still limited to the activities of the previous management and pattern of the last few years

\section{B. Character description of the Faculty of Social Sciences, Makassar State University}

Strong character is a fundamental grant that gives the human population the ability to live together in peace and form a world filled with goodness and virtue, free from violence and immoral actions

To get information about the student character of the Faculty of Social Sciences, Makassar State University can be seen on the chart.

Graph 2. A figure of Social Sciences Faculty of students of Makassar State University.

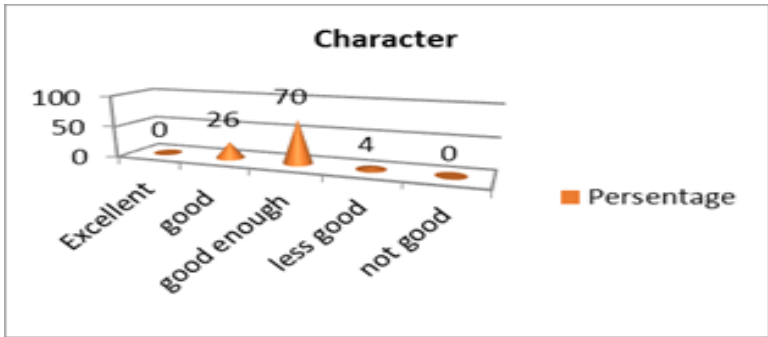

Based on the results of the descriptive data analysis above, it can be concluded that the students of the Faculty of the Social Sciences University of Makassar in the category of good enough, this activity organization are still oriented to the formalities that exist on campus

C. Organizational culture influence on the student character of the Faculty of Social Sciences Makassar State University

To test the hypothesis and to know about the relationship of cultural student organization Faculty of the Social Sciences University of Makassar to the student character Faculty of Social Sciences of Makassar State University, then held a correlation test product moment.

Table 1. Correlation of product-moment $\mathrm{X}$, and $\mathrm{Y}$

\section{Correlations}

\begin{tabular}{|c|c|c|c|}
\hline & & $\mathrm{X}$ & $\mathrm{Y}$ \\
\hline \multirow{4}{*}{$\mathrm{X}$} & Pearson Correlation & 1 & $.551^{* *}$ \\
\hline & Sig. (2-tailed) & & .000 \\
\hline & $\mathrm{N}$ & 90 & 90 \\
\hline & Pearson Correlation & $.551^{* *}$ & 1 \\
\hline \multirow[t]{2}{*}{ Y } & Sig. (2-tailed) & .000 & \\
\hline & $\mathrm{N}$ & 90 & 90 \\
\hline
\end{tabular}

Based on the product-moment calculation result, then obtained correlation between organization culture with students character Faculty of Social Sciences, Makassar State University with coefficient $\mathrm{r} 0.551$ then consulted on the Interpretation table $r$ value is at intervals. This means the cultural relationship of the Faculty of Social Sciences, Makassar State University organization with the student character Faculty of Social Sciences University of Makassar category medium.

To test the hypothesis in this study of "the cultural influence of the Faculty of Social Sciences, Makassar State University students ' organization on the character of the Faculty of Social Sciences, Makassar State University students partially", a double regression analysis was used.

Table 2. Regression X against $\mathrm{Y}$

Model Summary

\begin{tabular}{|c|r|r|r|r|}
\hline Model & \multicolumn{1}{|c|}{$\mathrm{R}$} & $\begin{array}{c}\mathrm{R} \\
\text { Square }\end{array}$ & $\begin{array}{c}\text { Adjusted } \\
\mathrm{R} \text { Square }\end{array}$ & $\begin{array}{c}\text { Std. The error of the } \\
\text { Estimate }\end{array}$ \\
\hline 1 & $.551^{\mathrm{a}}$ & .304 & .296 & 5.73691 \\
\hline
\end{tabular}

a. Predictors: (Constant), $\mathrm{X}$

b. Dependent Variable: Y

From the results of data is obtained value $\mathrm{R}$ square $=0.304$ meaning cultural variables student organization Faculty of Social Sciences of Makassar State University can explain the variability of $30.40 \%$ of the character variables of the Faculty of Social Sciences University of 
Makassar, while the rest is explained by other variables (where R2 is a coefficient of determination). For the significance testing of a regression coefficient can be performed by viewing the table results as follows:

Table 3. Coefficients Cultural Organization Coefficients

\begin{tabular}{|c|c|c|c|c|c|}
\hline \multirow[t]{2}{*}{ Model } & \multicolumn{2}{|c|}{$\begin{array}{l}\text { Unstandardize } \\
\text { d Coefficients }\end{array}$} & $\begin{array}{l}\text { Standard } \\
\text { ized } \\
\text { Coeffici } \\
\text { ents } \\
\end{array}$ & $\mathrm{t}$ & Sig. \\
\hline & B & $\begin{array}{l}\text { Std. } \\
\text { Error }\end{array}$ & Beta & & \\
\hline (Constant) & $\begin{array}{r}38.14 \\
4\end{array}$ & 4.665 & & 8.176 & $\begin{array}{r}.00 \\
0\end{array}$ \\
\hline$X$ & .248 & .040 & .551 & 6.199 & $\begin{array}{r}.00 \\
0\end{array}$ \\
\hline
\end{tabular}

a. Dependent Variable: Y

For hypothesis constants:

$\mathrm{H} 0$ : Regression coefficient is not significant

H1: Significant regression coefficient

In the level of significance $5 \%$, from the value of sig. $=$ 0.000 , more than the level of significance $5 \%$ so that it can be concluded that the decline Ho means a constant influence on student character Faculty of Social Sciences University of Makassar.

Hypothesis:

H0: Regression coefficient is not significant

H1: Significant regression coefficient

The level of significance is $5 \%$. The value of significance obtained is 0.000 smaller than the significance of $5 \%$. Then it can be concluded that the decline Ho means the student organization culture affects the student character of the Faculty of Social Sciences Makassar State University. So that regression model is formed.

$$
\mathrm{Y}=36,144+0,248(\mathrm{X})
$$

The + mark on the organizational culture variable shows the directional direction, meaning that if the student organization culture at the Faculty of Social Sciences of Makassar State University, the student character of the Faculty of Social Sciences of Makassar State University will be gained, so vice versa

Based on the results of the cultural description of the student organization of the Social Sciences Faculty of Makassar State University is in a good category. It is seen from the culture of the Organization as a pattern of basic assumptions found, researched, or developed by various groups that exist within the organization.

The results of this study in line with expressed the following organizational cultural characteristics:

a. Individual initiatives. Individual initiatives are the level of responsibility, freedom, or independence that each individual has in expressing opinions.

b. direction. The direction is intended to the extent that an organization can create the objectives and expectations desired. Those goals and expectations are reflected in the Organization's vision, mission, and objectives. c. integration. The extent to which organizations encourage organizational units to be able to cooperate in a coordinated manner.

d. support of the management. The extent to which the managers provide direction, assistance, and clear support of subordinates.

e. Communication patterns. To the extent that communication is limited by hierarchy, sometimes the hierarchy of authority can inhibit the occurrence of communication patterns between superiors and subordinates.

f. Tolerance to conflict. The extent to which employees are encouraged to openly express their opinions and criticism. Disagreements or criticism is a frequent phenomenon but can be used as a medium to make improvements or changes in strategies to achieve organizational objectives.

g. Control. The control tools used are the rules or norms that apply to an organization. It is necessary for several rules and supervisory personnel (direct rules) that can be used to supervise and control the behavior of employees within the organization.

h. Reward System. The extent to which the rewards allocation is based on employee achievement criteria as opposed to the seniority/select attitude of love.

i. Identity is a level whereby members identify with the organization as a whole from a particular working group or field of employment [14].

Based on the results of the study, that the student's character description is in a fairly good category, this is seen from the acquisition with the benchmark is the indicator Trustworthiness, the shape of the character that makes a person to integrate, honest, and loyal, Fairness, a form of character that makes a person has an open mind and does not like to utilize others, Caring, the form of the character that makes a person has scythe care and attention to the other people and, Respect, the form of character that makes one always appreciate and respect for others, Citizenship, the form of character that makes people aware of laws and regulations and cares for the natural environment, Responsibility, the form of character that makes a person responsible, disciplined, and always do something in the best possible. With the results of the analysis that the category is good enough.

The results of this research following the opinion stated that the character is a way of thinking and behaving that characterizes each individual to live and cooperate, both in the sphere of family, society, nation and State [15]. Unlike argues that the character is a characteristic of an object or individual (human) that characteristic is the original dang rooted in the personality of the object or individual and is a ' machine ' pusher how a person acts, behaves, says, and responds to something [16].

The results of this study with the title of the cultural relationship of the student organization to the student's character faculty of Social Sciences Makassar State University then held a correlation test product moment. Based on the product-moment calculation result, hence acquired correlation between culture organization with student character with a medium category. This means the 
cultural relationship of the organization with the student's character faculty of Social Sciences Makassar State University.

The results of the study following the opinion of that building the nation's character becomes a responsibility with all parties and components of this nation to get involved to condensing the sleeves build a strong and distinctive character so that all elements of society must engage build generation characters, among others:

a. Families should be involved in building their generational character through caring and parental awareness by an introduction to the generations.

b. Among the participants of educational institutions wherever the level and the strata in particular since the primary education, PAUD, Kindergarten, Elementary, then the higher level, JUNIOR high to the college by educators (teachers, lecturers, etc.) also have to be involved to build the character by teaching him and his students.

c. organizers (including in the organization are workers, employees, organizational activists, organizational leaders regardless of their organization, professional organizations, governments, or other institutions and institutions): to make them and to provide examples of the best example [17].

\section{CONCLUSION}

Based on the results of the research and the above discussion, the researcher draws the following conclusions:

1. The cultural overview of the organization of the students of the character faculty of Social Sciences Makassar State University is in a fairly good category, with benchmarks i.e. individual initiatives, briefing, integrate, support of management, pattern of communication patterns, tolerance, control, reward system, and identity.

2. The picture of the student's character is in the category quite well, it is seen from the acquisition with the benchmark is the indicator Trustworthiness, Fairness, Caring, Respect, Citizenship, Responsibility.

3. Based on the product-moment calculation result, then obtained a correlation between organization culture with student character faculty of Social Sciences Makassar State University with the medium category. This means cultural relations of the organization with the student's character faculty of Social Sciences Makassar State University

\section{ACKNOWLEDGMENT}

Thanks to the Dean of the Faculty of Social Sciences who have provided financial support for this research

\section{REFERENCES}

[1] N. Toyamah and S. Usman, "Alokasi Anggaran Pendidikan di Era Otonomi Daerah: Implikasinya terhadap Pengelolaan Pelayanan Pendidikan Dasar," Educ. Budg. Alloc. Era Reg. Auton. Its Implic. Basic Educ. Serv. Manag. Lap. Lapangan SMERU. Lemb. Penelit. SMERU, Jakarta, 2004.
[2] P. R. Indonesia, "Undang-undang Republik Indonesia nomor 20 tahun 2003 tentang sistem pendidikan nasional," Jakarta Pemerintah Republik Indones., 2003.

[3] L. Mona, "Mengembangkan 'Personal Social Resposibility (Psr)'Dalam Membangun Karakter Mahasiswa," J. Ilmu Komun. Acta Diurna, vol. 14, no. 2, pp. 30-47, 2018.

[4] T. P. K. B. B. Indonesia, "Kamus besar bahasa Indonesia," Jakarta: Balai Pustaka, 2008.

[5] I. Kartini and A. E. Rustanto, "Pengaruh Gaya Kepemimpinan Terhadap Budaya Organisasi Di Politeknik Lp3i Jakarta Kampus Jakarta Utara," J. LENTERA BISNIS, vol. 7, no. 1, pp. 56-66, 2018.

[6] F. Rahayu, "Hubungan Budaya Organisasi Dengan Kinerja Guru Di Sekolah Dasar Swasta Kecamatan Koto Tangah Padang," J. Bahana Manaj. Pendidik., vol. 2, no. 1, pp. 282-292, 2020.

[7] H. E. Sutrisno, Budaya organisasi. Prenada Media, 2019.

[8] A. A. ANDAYANI and T. D. Soehari, "Pengaruh Budaya Organisasi, Komitmen Organisasi dan Gaya Kepemimpinan terhadap Kinerja Karyawan," Akademika, vol. 8, no. 02, pp. 129-145, 2019.

[9] T. Lickona, "Character education: Seven crucial issues," Action Teach. Educ., vol. 20, no. 4, pp. 7784, 1999.

[10] R. N. Aulia, M. Firdaus, I. Mardhiah, and S. Narulita, "Pembentukan Nilai Karakter Peduli Lingkungan Studi Kasus Pondok Pesantren Darunnajah Cipining Bogor Oleh."

[11] R. JASPT, "Editorial JASPT Vol 1 No 1 Juli 2017," JAS-PT (Jurnal Anal. Sist. Pendidik. Tinggi Indones., vol. 1, no. 1, pp. i-iv, 2017.

[12] M. Muslich, "Pendidikan Karakter Menjawab Tantangan Krisis Multidimensional, cetakan ketiga," Jakarta Direktorat Pembin. Sekol. Dasar Direktorat Jendral Pendidik. Dasar dan Menengah Kementrian Pendidik. dan Kebud., 2013.

[13] A. S. Jahja, "Metodologi penelitian bisnis," 2013.

[14] W. Desriyeni, "Pengaruh Kepemimpinan Dan Budaya Organisasi Terhadap Kinerja Karyawan Pada Pt. Samudra Mandari Dumai Di Pekanbaru." Universitas Islam Negeri Sultan Syarif Kasim Riau, 2017.

[15] S. Sugiyarno, "Analisis of the Implementation Character Education at SMP 1 Wonogiri at Academic Year 2012/2013," J. Teknol. Pendidik. dan Pembelajaran, vol. 2, no. 1, p. 142155.

[16] A. Syarbini, Model Pendidikan Karakter dalam Keluarga. Elex Media Komputindo, 2014.

[17] N. Ro'fah, “Pengelolaan Pembelajaran Pendidikan Anak Usia Dini dalam Membentuk Karakter Peserta Didik di RA Al Makmur Cikarang Utara (Dalam Perspektif Manajemen Kurikulum).” Jakarta: FITK UIN Syarif Hidayatullah Jakarta. 